\title{
Disintegrating Tablet Dosage Form
}

National Cancer Institute

\section{Source}

National Cancer Institute. Disintegrating Tablet Dosage Form. NCI Thesaurus. Code C69071.

A tablet that dissolves or melts quickly (usually within a matter of seconds) when it comes into contact with a liquid. 